\title{
ANALYSIS OF TEACHER EDUCATION AND TRAINING PROGRAMS OF PAKISTAN FOR ICT-INTEGRATION THROUGH OPEN AND DISTANCE LEARNING: A CASE STUDY
}

By

\author{
Yousaf Khan*
}

\begin{abstract}
The purpose of the study was to analyze the teacher education and training program of Pakistan for ICT-integration. It was hypothesized that there is a possibility to integrate Information and Communication Technology in teacher education and training program of Pakistan. It is a case study with the objective to analyze the teacher education program of Pakistan for the possibility to integrate-Information and Communication Technology through Open and Distance Learning. The sample comprised of all students of M.Ed Distance Education Program of University of Peshawar enrolled in session 2013. The data was collected through a self-made three point rating scale comprising 58 factorized statements. The collected data was analyzed by computing percentages and applying chi square for interpretation of significance and inference. The results of study revealed that there is possibility of ICT-integration with teacher education especially through Open and Distance Learning System but there are threats and challenges also to be faced and resolved for this purpose. The results revealed need for a policy framework, revision of objectives, whole school Information and Communication Technology literacy campaign, introduction of Information and Communication Technology at all levels of schooling, training of educators, development of curricula and training modules, presentation, production and development of econtent, resolving the issues of connectivity, power crisis, religious conflicts, developing and utilizing existing infrastructure, developing curricula at all levels of schooling for ICT-infusion. The study recommends commitment to resolve issues, face threats and converting these threats and challenges to opportunities in teacher education of Pakistan through Open and Distance Learning System.
\end{abstract}

Keywords: Teacher Education, ICT-Integration, Open and Distance Learning.

* Deputy District Education Officer in Elementary and Secondary Education, Khyber Pakhtunkhwa (Pakistan) 


\section{Introduction}

The world view of teacher training program reflects the phenomenon of Information and Communication Technology transformation. Advancement in technology requires every person matured enough to handle and manipulate data into his/her computer/calculator or mobile phone. The mobile phones literacy is emerging as a component to be included in the definition of literacy along with the other three skills of reading, writing and arithmetic, i.e. Information and Communication Technology (ICT). When a child without schooling/formal education can comprehend such an advanced Information and Communication Technology (ICT) tools then why not a teacher be trained through these technological tools. Use of advanced ICT may enhance the scope of trained personnel as they will be having advanced knowledge, understanding, comprehension etc. (cognition). They can develop their interest, changing their attitude, and appreciate new values. The teachers can acquire new habits and skills (Psychomotor development) through the use of new technology in their daily life; at home, school and community as well as in their professional life. So a teacher can regulate his/her own learning through Information and Communication Technology.

Otieno (2008, p. iv) discussed a framework for using Information and Communication Technology in teacher education and said that teachers are under increased pressure to use Information and Communication Technology in order to impart knowledge, skills and attitudes to meet the challenges of $21^{\text {st }}$ century. The teaching profession needs to migrate from teacher-centered lecture-base instruction to student centered interactive learning environment in which learning is self-regulated.

Afzal (2009) in his study has suggested that teacher training should have infusion of Information and Communication Technology in Pakistan. It means that Information and Communication Technology is creeping in the education system of Pakistan.

Open and Distance Learning (ODL) is flexible, time-free, age-free, space or location-free but technology bound (Khan, 2014). This phenomenon is seen all over the world including teacher education. In Pakistan, Allama Iqbal Open University, Virtual University, Sarhad University and now some Dual Mode Universities such as University of Peshawar, Gomal University etc. are competing to provide teacher education through distance mode.

In Open and Distance Learning the pedagogy is shifted to andragogy where the learners themselves are self-motivated to learn by using self-regulated and self-paced methodologies and technologies while the tutors and instructors facilitates, guides and mentors and the instructional technology used in this system requires integration of Information and Communication Technology with education. So, that learning and pedagogy would be more facilitated.

The effective pedagogy used in ICT-Integrated learning and teaching is cognitive apprenticeship (Khan, 2014) which also requires the application of learning theories in E-Learning. In this scenario, the present study was designed to analyze the teacher training program of Pakistan for ICT-Integration through Open and Distance Learning System. 


\section{Objectives}

The study intended to achieve the following objectives:

1. To analyze the existing teacher education programs for the extent of use of Information and Communication Technology.

2. To find the strengths and weaknesses of the existing teacher education program for ICT-integration.

3. To determine the possibility and opportunities to integrate Information and Communication Technology in teacher training program of Pakistan through Open and Distance Learning.

4. To make recommendation for ICT-integration in teacher training program of Pakistan through Open and Distance Learning System.

\section{Hypotheses}

$\mathrm{H}_{0}$ : Teacher Education of Pakistan is having no possibility to integrate ICT in the teacher training programs through Open and Distance Learning System.

$\mathrm{H}_{\mathrm{A}}$ : Teacher Education of Pakistan is having possibility to integrate ICT in the teacher training program through Open and Distance Learning System.

\section{Methodology}

The study was descriptive in nature as it described the possibility to integrate ICT in teacher education of Pakistan. It was a case study because the data was collected in only one institution offering distance education of Peshawar University in a learning center of district Swat. But, it was an intensive and extensive study to cover all aspects of teacher education in Pakistan.

\section{Population}

The population of the study consisted of all the students of Master of Education (M.Ed) with the area of specialization of teacher education enrolled in the session 2013.

\section{Sample}

The sample of the study consisted of the students of Master of Education (M.Ed) having teacher education as a special area in the distance education program of Peshawar University for the session 2013 in the learning centre of District Swat.

\section{Research Instrument}

The instrument used for the study was a questionnaire developed by the researcher after thorough literature review on the integrated use of Information and Communication Technology in teacher training and education all over the world.

The questionnaire consisted of 58 statements factorized into fourteen main categories covering all aspects of teacher education to analyze the program for ICTintegration in Pakistan through Open and Distance Learning. 


\section{Pilot Testing}

The instrument containing 57 statements developed on Thurston scale was pilot tested through Ph.D scholar of Secondary Teacher Education in a workshop on $21^{\text {st }}$ January, 2013. On the basis of pilot testing the instrument was modified by adding one item as recommn3eded by the judges. Hence, the final rating scale consisted of 58 statements to be evaluated on 3 point scale (agreed, undecided and disagreed).

\section{Data Collection and Analysis}

The data was collected through questionnaire by the researcher himself. The data was tabulated and analyzed on the basis of percentages while chi square test was used for testing the hypothesis for its significance, interpretation and drawing inferences and conclusion.

\section{Results}

1. Policy framework for ICT-integration in teacher training of Pakistan.

Table 1

Showing frequency, percentage, chi square $(n=17)$ and significance for the statements about policy framework

\begin{tabular}{|c|c|c|c|c|c|c|}
\hline S.No & $\begin{array}{l}\text { Statement } \\
\end{array}$ & $\begin{array}{c}\text { Agreed } \\
\text { f (\%) }\end{array}$ & $\begin{array}{l}\text { UND } \\
\text { f (\%) }\end{array}$ & $\begin{array}{c}\text { Disagreed } \\
\mathrm{f}(\%)\end{array}$ & $\begin{array}{c}\text { Chi square } \\
\left(\chi^{2}\right)\end{array}$ & $\begin{array}{c}\text { Inference } \\
\chi_{0.05}^{2} \\
\text { at d.f }=1\end{array}$ \\
\hline 1 & $\begin{array}{l}\text { The teacher training program in Pakistan is } \\
\text { supporting ICT integration policy. }\end{array}$ & $\begin{array}{c}2 \\
(11.76)\end{array}$ & $\begin{array}{c}0 \\
(0.0)\end{array}$ & $\begin{array}{c}15 \\
(88.23)\end{array}$ & 9.94 & $\begin{array}{l}\text { Significant } \\
\text { (Disagreed) }\end{array}$ \\
\hline 2 & $\begin{array}{l}\text { There is no ICT integration policy in teacher } \\
\text { training and education of Pakistan. }\end{array}$ & $\begin{array}{c}12 \\
(70.6)\end{array}$ & $\begin{array}{c}1 \\
(5.88)\end{array}$ & $\begin{array}{c}4 \\
(23.5)\end{array}$ & 3.82 & $\begin{array}{l}\text { In significant } \\
\text { (Agreed) }\end{array}$ \\
\hline
\end{tabular}

Table 1 indicates that significant number of respondents disagreed that the teacher training program in Pakistan is supporting ICT-integration policy and insignificant number of respondent agreed that there is no ICT-integration policy in teacher training and education of Pakistan.

\section{Objectives of Teacher Training for ICT-integration.}

Table 2

Showing frequency, percentage, chi square $(n=17)$ and significance for the statements about objective

\begin{tabular}{ccccccc}
\hline \hline S.No & Statement & Agreed & UND & Disagreed & Chi square & Inference \\
& $\mathrm{f}(\%)$ & $\mathrm{f}(\%)$ & $\mathrm{f}(\%)$ & $\left(\chi^{2}\right)$ & $\begin{array}{c}\chi_{0.05}^{2} \\
\text { at d.f }=1\end{array}$ \\
& & & & & & \\
\hline \hline
\end{tabular}


Analysis of Teacher Education and Training Programs of Pakistan for ICT-Integration

\begin{tabular}{|c|c|c|c|c|c|c|}
\hline$\overline{3}$ & $\begin{array}{l}\text { The teacher training program in Pakistan has } \\
\text { the objectives to develop/upgrade knowledge } \\
\text { and skills in basic computer literacy. }\end{array}$ & $\begin{array}{c}1 \\
(5.88)\end{array}$ & $\begin{array}{c}0 \\
(0.0)\end{array}$ & $\begin{array}{c}16 \\
(94.11)\end{array}$ & 13.22 & $\begin{array}{l}\text { Significant } \\
\text { (Disagreed) }\end{array}$ \\
\hline 4 & $\begin{array}{l}\text { The teacher training program in Pakistan has no } \\
\text { objectives to integrate use of ICT in teacher } \\
\text { training. }\end{array}$ & $\begin{array}{c}10 \\
(58.82)\end{array}$ & $\begin{array}{c}0 \\
(0.0)\end{array}$ & $\begin{array}{c}7 \\
(41.18)\end{array}$ & 0.52 & $\begin{array}{l}\text { In significant } \\
\text { (Agreed) }\end{array}$ \\
\hline 5 & $\begin{array}{l}\text { The teacher training program in Pakistan has no } \\
\text { objective to develop specific/ concrete } \\
\text { competencies to be improved among teachers } \\
\text { and other professionals, through ICT. }\end{array}$ & $\begin{array}{c}12 \\
(70.6)\end{array}$ & $\begin{array}{c}1 \\
(5.88)\end{array}$ & $\begin{array}{c}4 \\
(23.5)\end{array}$ & 3.82 & $\begin{array}{l}\text { In significant } \\
\text { (Agreed) }\end{array}$ \\
\hline
\end{tabular}

Table 2 indicates that significant number of respondents disagreed that the teacher training program in Pakistan has the objectives to develop and upgrade knowledge and skill in basic computer literacy and insignificant number agreed that there is no objective to integrate use of Information and Communication Technology and develop competencies of teacher for Information and Communication Technology use in their pedagogy.

\section{Scope of Teacher Training for ICT use in Pakistan.}

Table 3

Showing frequency, percentage, chi square $(n=17)$ and significance for the statements about the scope of Teacher Training for ICT use

\begin{tabular}{|c|c|c|c|c|c|c|}
\hline S.No & Statement & $\begin{array}{l}\text { Agreed } \\
\mathrm{f}(\%)\end{array}$ & $\begin{array}{l}\text { UND } \\
\text { f (\%) }\end{array}$ & $\begin{array}{l}\text { Disagreed } \\
\mathrm{f}(\%)\end{array}$ & $\begin{array}{l}\text { Chi square } \\
\left(\chi^{2}\right)\end{array}$ & $\begin{array}{l}\text { Inference } \\
\chi_{0.05}^{2} \\
\text { at d.f }=1\end{array}$ \\
\hline 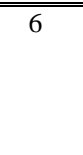 & $\begin{array}{l}\text { In teacher training program of Pakistan the } \\
\text { importance of developing teacher skills in } \\
\text { computer configuration and troubleshooting is } \\
\text { beginning to be realized by only a few programs. }\end{array}$ & $\begin{array}{c}11 \\
(64.7)\end{array}$ & $\begin{array}{c}1 \\
(5.88)\end{array}$ & $\begin{array}{c}5 \\
(29.41)\end{array}$ & 2.17 & $\begin{array}{c}\text { In significant } \\
\text { (Agreed) }\end{array}$ \\
\hline 7 & $\begin{array}{l}\text { In teacher training program of Pakistan, skills to } \\
\text { undertake online collaboration are gaining } \\
\text { ground but require strong connectivity. }\end{array}$ & $\begin{array}{c}16 \\
(94.11)\end{array}$ & $\begin{array}{c}0 \\
(0.0)\end{array}$ & $\begin{array}{c}1 \\
(5.88)\end{array}$ & 13.22 & $\begin{array}{l}\text { Significant } \\
\text { (Agreed) }\end{array}$ \\
\hline 8 & $\begin{array}{l}\text { In teacher training program of Pakistan, a few } \\
\text { training programs also go beyond school based } \\
\text { training by offering training to the community } \\
\text { (or reaching the community). }\end{array}$ & $\begin{array}{c}2 \\
(11.76)\end{array}$ & $\begin{array}{c}1 \\
(5.88)\end{array}$ & $\begin{array}{c}14 \\
(82.35)\end{array}$ & 8.52 & $\begin{array}{l}\text { Significant } \\
\text { (Disagreed) }\end{array}$ \\
\hline 9 & $\begin{array}{l}\text { The teacher training program of Pakistan are } \\
\text { providing technical advice and support or } \\
\text { continuing follow up support. }\end{array}$ & $\begin{array}{c}3 \\
(17.64)\end{array}$ & $\begin{array}{c}1 \\
(5.88)\end{array}$ & $\begin{array}{c}13 \\
(76.47)\end{array}$ & 5.93 & $\begin{array}{l}\text { Significant } \\
\text { (Disagreed) }\end{array}$ \\
\hline 10 & $\begin{array}{l}\text { The teacher training program of Pakistan is } \\
\text { providing both types of training in ICT: pre- } \\
\text { service and in-service. }\end{array}$ & $\begin{array}{c}6 \\
(35.29)\end{array}$ & $\begin{array}{c}0 \\
(0.0)\end{array}$ & $\begin{array}{c}11 \\
(64.70)\end{array}$ & 1.46 & $\begin{array}{l}\text { In significant } \\
\text { (Disagreed) }\end{array}$ \\
\hline 11 & $\begin{array}{l}\text { The teacher training programs do not provide } \\
\text { training in ICT in all subjects but in few areas. }\end{array}$ & $\begin{array}{c}6 \\
(35.29)\end{array}$ & $\begin{array}{c}1 \\
(5.88)\end{array}$ & $\begin{array}{c}10 \\
(58.82)\end{array}$ & 0.99 & $\begin{array}{l}\text { In significant } \\
\text { (Disagreed) }\end{array}$ \\
\hline 12 & $\begin{array}{l}\text { The teacher training program provides training in } \\
\text { ICT to the administration/non-teaching staff. }\end{array}$ & $\begin{array}{c}2 \\
(11.76)\end{array}$ & $\begin{array}{c}2 \\
(11.76)\end{array}$ & $\begin{array}{c}13 \\
(76.47)\end{array}$ & 7.35 & $\begin{array}{r}\text { Significant } \\
\text { (Disagreed) }\end{array}$ \\
\hline
\end{tabular}

Table 3 indicates that insignificant number of teachers agreed that there is realization of developing teacher skills in computer configuration, trouble shooting and technology, use online collaboration, community reach, continuing follow up, pre-service and in-service training, training in all subjects and areas and to train administrative and non-teaching staff for effective communication and linkages. 


\section{Use of ICT as Training Media at different levels in Teacher Training of Pakistan.}

Table 4

Showing frequency, percentage, chi square $(n=17)$ and significance for the use of ICT as training media

\begin{tabular}{|c|c|c|c|c|c|c|}
\hline S.No & Statement & $\begin{array}{c}\text { Agreed } \\
\mathrm{f}(\%)\end{array}$ & $\begin{array}{l}\text { UND } \\
\mathrm{f}(\%)\end{array}$ & $\begin{array}{l}\text { Disagreed } \\
\mathrm{f}(\%)\end{array}$ & $\begin{array}{l}\text { Chi square } \\
\left(\chi^{2}\right)\end{array}$ & $\begin{array}{l}\text { Inference } \\
\chi_{0.05}^{2} \\
\text { at d.f }=1\end{array}$ \\
\hline 13 & $\begin{array}{l}\text { The teacher training program uses ICT as training } \\
\text { media but not as training with ICT (ICT as a mode } \\
\text { of instruction). }\end{array}$ & $\begin{array}{c}10 \\
(58.82)\end{array}$ & $\begin{array}{c}1 \\
(5.88)\end{array}$ & $\begin{array}{c}6 \\
(35.29)\end{array}$ & 0.99 & $\begin{array}{l}\text { In significant } \\
\text { (Agreed) }\end{array}$ \\
\hline 14 & $\begin{array}{l}\text { The teacher training program has no use of ICT } \\
\text { for pre-service teacher training. }\end{array}$ & $\begin{array}{c}5 \\
(29.41)\end{array}$ & $\begin{array}{c}1 \\
(5.88)\end{array}$ & $\begin{array}{c}11 \\
(64.70)\end{array}$ & 2.17 & $\begin{array}{l}\text { In significant } \\
\text { (Disagreed) }\end{array}$ \\
\hline 15 & $\begin{array}{l}\text { The teacher training program of Pakistan is using } \\
\text { ICT based teacher training program for all levels: } \\
\text { primary, secondary and collegiate. }\end{array}$ & $\begin{array}{c}3 \\
(17.64)\end{array}$ & $\begin{array}{c}0 \\
(0.0)\end{array}$ & $\begin{array}{c}14 \\
(82.35)\end{array}$ & 7.06 & $\begin{array}{l}\text { Significant } \\
\text { (Disagreed) }\end{array}$ \\
\hline 16 & $\begin{array}{l}\text { The teacher training program of Pakistan is not } \\
\text { using ICT based pre-service training for secondary } \\
\text { school teachers. }\end{array}$ & $\begin{array}{c}15 \\
(88.23)\end{array}$ & $\begin{array}{c}1 \\
(5.88)\end{array}$ & $\begin{array}{c}1 \\
(5.88)\end{array}$ & 11.6 & $\begin{array}{l}\text { Significant } \\
\text { (Agreed) }\end{array}$ \\
\hline 17 & $\begin{array}{l}\text { Significant numbers of teachers in Pakistan are } \\
\text { trained through ICT or with ICT. }\end{array}$ & $\begin{array}{c}2 \\
(11.76)\end{array}$ & $\begin{array}{c}0 \\
(0.0)\end{array}$ & $\begin{array}{c}15 \\
(88.23)\end{array}$ & 9.94 & $\begin{array}{l}\text { Significant } \\
\text { (Disagreed) }\end{array}$ \\
\hline 18 & $\begin{array}{l}\text { Significant numbers of pre-service teachers are } \\
\text { being trained with ICT or through e-learning. }\end{array}$ & $\begin{array}{c}2 \\
(11.76)\end{array}$ & $\begin{array}{c}0 \\
(0.0)\end{array}$ & $\begin{array}{c}15 \\
(88.23)\end{array}$ & 9.94 & $\begin{array}{l}\text { Significant } \\
\text { (Disagreed) }\end{array}$ \\
\hline 19 & $\begin{array}{l}\text { The teacher training program with ICT is limited } \\
\text { to few cities and institutions. }\end{array}$ & $\begin{array}{c}15 \\
(88.23)\end{array}$ & $\begin{array}{c}1 \\
(5.88)\end{array}$ & $\begin{array}{c}1 \\
(5.88)\end{array}$ & 11.6 & $\begin{array}{l}\text { Significant } \\
\text { (Agreed) }\end{array}$ \\
\hline 20 & $\begin{array}{l}\text { The teacher training program with ICT is located } \\
\text { in specific institution or universities such as AIOU } \\
\text { and Virtual University or Intel and Agha Khan } \\
\text { Institute. }\end{array}$ & $\begin{array}{c}17 \\
(100)\end{array}$ & $\begin{array}{c}0 \\
(0.0)\end{array}$ & $\begin{array}{c}0 \\
(0.0)\end{array}$ & 8.5 & $\begin{array}{l}\text { Significant } \\
\text { (Agreed) }\end{array}$ \\
\hline 21 & $\begin{array}{l}\text { The duration of teacher training in ICT is two } \\
\text { weeks. }\end{array}$ & $\begin{array}{c}1 \\
(5.88)\end{array}$ & $\begin{array}{c}3 \\
(17.64)\end{array}$ & $\begin{array}{c}13 \\
(76.47)\end{array}$ & 8.99 & $\begin{array}{l}\text { Significant } \\
\text { (Disagreed) }\end{array}$ \\
\hline
\end{tabular}

Table 4 indicates that insignificant number of respondent agreed to use Information and Communication Technology as training media but not as training with Information and Communication Technology, there is no use of Information and Communication Technology for pre-services teacher training and there is no use for primary, secondary and collegiate teacher training. Also significant number of teacher disagreed that in Pakistan teachers are trained through Information and Communication Technology or with Information and Communication Technology or e-learning and the facilities are limited to few institutions such as Allam Iqbal Open University, Virtual University, Agha Khan Institute and Intel and that there is no training in Information and Communication Technology for about two weeks or of short duration in other institutions.

\section{Training of Teacher Trainer or Educator with ICT use in Pakistan.}

Table 5

Showing frequency, percentage, chi square $(n=17)$ and significance for the statements about training of teacher trainer or Educator 
Analysis of Teacher Education and Training Programs of Pakistan for ICT-Integration

\begin{tabular}{|c|c|c|c|c|c|c|}
\hline S.No & $\begin{array}{l}\text { Statement } \\
\end{array}$ & $\begin{array}{c}\text { Agreed } \\
\text { f (\%) }\end{array}$ & $\begin{array}{l}\text { UND } \\
\mathrm{f}(\%)\end{array}$ & $\begin{array}{c}\text { Disagreed } \\
\mathrm{f}(\%)\end{array}$ & $\begin{array}{l}\text { Chi square } \\
\left(\chi^{2}\right)\end{array}$ & $\begin{array}{l}\text { Inference } \\
\chi_{0.05}^{2} \\
\text { at d.f }=1\end{array}$ \\
\hline 22 & $\begin{array}{l}\text { The teacher educator and trainer in Pakistan are } \\
\text { mostly ICT literate and expert to provide } \\
\text { training in ICT integrated curricula. }\end{array}$ & $\begin{array}{c}0 \\
(0.0)\end{array}$ & $\begin{array}{c}0 \\
(0.0)\end{array}$ & $\begin{array}{c}17 \\
(100)\end{array}$ & 8.5 & $\begin{array}{r}\text { Significant } \\
\text { (Disagreed) }\end{array}$ \\
\hline 23 & $\begin{array}{l}\text { The teacher trainers in ICT are replaced by peer } \\
\text { approaches type training to provide training in } \\
\text { ICT skills to one another. }\end{array}$ & $\begin{array}{c}4 \\
(23.5)\end{array}$ & $\begin{array}{c}4 \\
(23.5)\end{array}$ & $\begin{array}{c}9 \\
(52.94)\end{array}$ & 2.40 & $\begin{array}{l}\text { In significant } \\
\text { (Disagreed) }\end{array}$ \\
\hline
\end{tabular}

Table-5 indicates that all the respondents disagreed that teacher educator are trained with Information and Communication Technology use and insignificant number of respondents disagreed that there are peer approaches type training.

\section{Issue to develop Curricula and Training Modules for ICT-integrated Program in Pakistan.}

Table 6

Showing frequency, percentage, chi square $(n=17)$ and significance for the statements about the issue to develop curricula and training modules

\begin{tabular}{|c|c|c|c|c|c|c|}
\hline S.No & Statement & $\begin{array}{c}\text { Agreed } \\
\mathrm{f}(\%)\end{array}$ & $\begin{array}{l}\text { UND } \\
\mathrm{f}(\%)\end{array}$ & $\begin{array}{c}\text { Disagreed } \\
\mathrm{f}(\%)\end{array}$ & $\begin{array}{l}\text { Chi square } \\
\left(\chi^{2}\right)\end{array}$ & $\begin{array}{l}\text { Inference } \\
\chi_{0.05}^{2} \\
\text { at d.f }=1\end{array}$ \\
\hline 24 & $\begin{array}{l}\text { The teacher training in ICT integrated curricula } \\
\text { in Pakistan is usually sponsored by the donor } \\
\text { agencies and not the government such as Intel- } \\
\text { sponsored programs. }\end{array}$ & $\begin{array}{c}14 \\
(82.35)\end{array}$ & $\begin{array}{c}1 \\
(5.88)\end{array}$ & $\begin{array}{c}2 \\
(11.76)\end{array}$ & 8.53 & $\begin{array}{l}\text { Significant } \\
\text { (Agreed) }\end{array}$ \\
\hline 25 & $\begin{array}{l}\text { The ICT integrated teacher training program } \\
\text { could not be flourished due to the issue of cost in } \\
\text { developing modules. }\end{array}$ & $\begin{array}{c}16 \\
(94.11)\end{array}$ & $\begin{array}{c}0 \\
(0.0)\end{array}$ & $\begin{array}{c}1 \\
(5.88)\end{array}$ & 13.22 & $\begin{array}{l}\text { Significant } \\
\text { (Agreed) }\end{array}$ \\
\hline 26 & $\begin{array}{l}\text { The modules in ICT integrated teacher training in } \\
\text { Pakistan are required/needed to be adopted in } \\
\text { local environment. }\end{array}$ & $\begin{array}{c}15 \\
(88.23)\end{array}$ & $\begin{array}{c}0 \\
(0.0)\end{array}$ & $\begin{array}{c}2 \\
(11.76)\end{array}$ & 9.94 & $\begin{array}{l}\text { Significant } \\
\text { (Agreed) }\end{array}$ \\
\hline 27 & $\begin{array}{l}\text { The training scheme, in teacher training program } \\
\text { with ICT in Pakistan has the issue of cascade } \\
\text { type or peer-training approaches and they skip } \\
\text { pilot testing. }\end{array}$ & $\begin{array}{c}4 \\
(23.5\end{array}$ & $\begin{array}{c}5 \\
(29.41)\end{array}$ & $\begin{array}{c}8 \\
(47.05)\end{array}$ & 2.67 & $\begin{array}{c}\text { In significant } \\
\text { (Disagreed) }\end{array}$ \\
\hline
\end{tabular}

Table-6 indicates that significant number of respondent agreed that teacher training in ICT integrated curricula in Pakistan is usually sponsored by the donor agencies and not by the Government, there is the issue of cost in developing module and adaptation is also required in local environment while insignificant number of respondents disagreed that there is the issue of cascade type or peer-training approaches and they skip pilot testing.

\section{Issue related to ICT-integrated content presentation in teacher training of Pakistan.}

Table 7

Showing frequency, percentage, chi square $(n=17)$ and significance for the statements about the issue of content presentation

\begin{tabular}{lcccccc}
\hline \hline S.No & Statement & Agreed & UND & Disagreed & Chi square & Inference \\
& & $\mathrm{f}(\%)$ & $\mathrm{f}(\%)$ & $\mathrm{f}(\%)$ & $\left(\chi^{2}\right)$ & $\begin{array}{c}\chi_{0.05}^{2} \\
\text { at d.f }=1\end{array}$ \\
& & & & & & \\
\hline \hline
\end{tabular}




\begin{tabular}{|c|c|c|c|c|c|c|}
\hline 28 & $\begin{array}{l}\text { In teacher training program of Pakistan to adopt } \\
\text { ICT integrated content has faced the issues of } \\
\text { access: to online, language, program coverage, } \\
\text { infrastructure and copyright. }\end{array}$ & $\begin{array}{c}17 \\
(100)\end{array}$ & $\begin{array}{c}0 \\
(0.0)\end{array}$ & $\begin{array}{c}0 \\
(0.0)\end{array}$ & 8.5 & $\begin{array}{c}\text { Significant } \\
\text { (Agreed) }\end{array}$ \\
\hline 29 & $\begin{array}{l}\text { The key issue in teacher training program of } \\
\text { Pakistan is to integrate ICT infrastructure to } \\
\text { provide adequate access to the internet. }\end{array}$ & $\begin{array}{c}15 \\
(88.23)\end{array}$ & $\begin{array}{c}1 \\
(5.88)\end{array}$ & $\begin{array}{c}1 \\
(5.88)\end{array}$ & 11.58 & $\begin{array}{l}\text { Significant } \\
\text { (Agreed) }\end{array}$ \\
\hline 30 & $\begin{array}{l}\text { There is the issue of power/electricity to integrate } \\
\text { ICT in teacher training program of Pakistan. }\end{array}$ & $\begin{array}{c}17 \\
(100)\end{array}$ & $\begin{array}{c}0 \\
(0.0)\end{array}$ & $\begin{array}{c}0 \\
(0.0)\end{array}$ & 8.5 & $\begin{array}{c}\text { Significant } \\
\text { (Agreed) }\end{array}$ \\
\hline
\end{tabular}

Table-7 indicates that all respondents agreed that teacher training program in Pakistan has faced the issues of access to online, language, program coverage, infrastructure and copyright and there is the issue of power break down, energy crises and internet connectivity to integrate Information and Communication Technology in teacher training program.

\section{Issue of e-Content production and development in Teacher Training program of Pakistan.}

Table 8

Showing frequency, percentage, chi square $(n=17)$ and significance for the statements about the e-content production and developed

\begin{tabular}{|c|c|c|c|c|c|c|}
\hline S.No & Statement & $\begin{array}{c}\text { Agreed } \\
\mathrm{f}(\%)\end{array}$ & $\begin{array}{l}\text { UND } \\
\mathrm{f}(\%)\end{array}$ & $\begin{array}{l}\text { Disagreed } \\
\mathrm{f}(\%)\end{array}$ & $\begin{array}{l}\text { Chi square } \\
\qquad\left(\chi^{2}\right)\end{array}$ & $\begin{array}{l}\text { Inference } \\
\chi_{0.05}^{2} \\
\text { at d.f }=1\end{array}$ \\
\hline 31 & $\begin{array}{l}\text { In Pakistan, the teacher training program has } \\
\text { produced modules for training with ICT. }\end{array}$ & $\begin{array}{c}5 \\
(29.41)\end{array}$ & $\begin{array}{c}3 \\
(17.64)\end{array}$ & $\begin{array}{c}9 \\
(52.94)\end{array}$ & 1.47 & $\begin{array}{l}\text { In significant } \\
\text { (Disagreed) }\end{array}$ \\
\hline 32 & $\begin{array}{l}\text { The content focus in teacher training program of } \\
\text { Pakistan with ICT is being hardware and software } \\
\text { applications oriented with no link to } \\
\text { teaching/learning. }\end{array}$ & $\begin{array}{c}5 \\
(29.41)\end{array}$ & $\begin{array}{c}3 \\
(17.64)\end{array}$ & $\begin{array}{c}9 \\
(52.94)\end{array}$ & 1.47 & $\begin{array}{l}\text { In significant } \\
\text { (Disagreed) }\end{array}$ \\
\hline 33 & $\begin{array}{l}\text { The content focus in teacher training program of } \\
\text { Pakistan with ICT is more pedagogy based and } \\
\text { there is no integrated use of ICT. }\end{array}$ & $\begin{array}{c}13 \\
(76.47)\end{array}$ & $\begin{array}{c}1 \\
(5.88)\end{array}$ & $\begin{array}{c}3 \\
(17.64)\end{array}$ & 5.94 & $\begin{array}{l}\text { Significant } \\
\text { (Agreed) }\end{array}$ \\
\hline 34 & $\begin{array}{l}\text { The content focus in teacher training program of } \\
\text { Pakistan is neither ICT applications oriented nor } \\
\text { pedagogy based integrated ICT. }\end{array}$ & $\begin{array}{c}8 \\
(47.05)\end{array}$ & $\begin{array}{c}3 \\
(17.64)\end{array}$ & $\begin{array}{c}6 \\
(35.29)\end{array}$ & 0.76 & $\begin{array}{l}\text { In significant } \\
\text { (Agreed) }\end{array}$ \\
\hline 35 & $\begin{array}{l}\text { In teacher training program of Pakistan, the } \\
\text { content focus in some subjects is learning with } \\
\text { ICT. }\end{array}$ & $\begin{array}{c}7 \\
(41.17)\end{array}$ & $\begin{array}{c}1 \\
(5.88)\end{array}$ & $\begin{array}{c}9 \\
52.94\end{array}$ & 0.29 & $\begin{array}{l}\text { In significant } \\
\text { (Disagreed) }\end{array}$ \\
\hline 36 & $\begin{array}{l}\text { In teacher training of Pakistan the content focus in } \\
\text { all subjects/areas is learning with ICT. }\end{array}$ & $\begin{array}{c}3 \\
17.64\end{array}$ & $\begin{array}{c}0 \\
(0.0)\end{array}$ & $\begin{array}{c}14 \\
(82.35)\end{array}$ & 7.12 & $\begin{array}{l}\text { Significant } \\
\text { (Disagreed) }\end{array}$ \\
\hline
\end{tabular}

Table-8 indicates that insignificant number of respondents disagreed that in Pakistan, the teacher training program has produced modules for training with Information and Communication Technology and that the content focus in teacher training program of Pakistan is neither Information and Communication Technology application nor pedagogy based integrated ICT. As significant number of respondents also disagreed that the content focus in all subjects/area is learning with Information and Communication Technology.

\section{Use of online Tools and Collaborations in Teacher Training of Pakistan.}


Table 9

Showing frequency, percentage, chi square $(n=17)$ and significance for the statements about use of online tools and collaboration

\begin{tabular}{clccccc}
\hline \hline S.No & \multicolumn{1}{c}{ Statement } & $\begin{array}{c}\text { Agreed } \\
\mathrm{f}(\%)\end{array}$ & $\begin{array}{c}\text { UND } \\
\mathrm{f}(\%)\end{array}$ & $\begin{array}{c}\text { Disagreed } \\
\mathrm{f}(\%)\end{array}$ & $\begin{array}{c}\text { Chi square } \\
\left(\chi^{2}\right)\end{array}$ & $\begin{array}{c}\text { Inference } \\
\chi_{0.05}^{2} \\
\text { at d.f }=1\end{array}$ \\
\hline \hline 37 & $\begin{array}{l}\text { Online communication tools are used in teacher } \\
\text { training program of Pakistan such as internet and } \\
\text { online collaboration. }\end{array}$ & $\begin{array}{c}(29.41) \\
\text { There is possibility to use tele-collaboration or } \\
\text { video conferencing in teacher training of } \\
\text { Pakistan. }\end{array}$ & $\begin{array}{c}17 \\
(100)\end{array}$ & $\begin{array}{c}(5.88) \\
(0.0)\end{array}$ & $\begin{array}{c}(64.70) \\
\text { (Disagreed) }\end{array}$ \\
\hline \hline
\end{tabular}

Table-9 indicates that insignificant number of respondents disagreed that there is internet based or online collaboration and all the respondents agreed that there is possibility to use tele-collaboration or video conferencing in teacher training programs of Pakistan.

10. Opportunities for ICT integration in Teacher Training of Pakistan.

Table 10

Showing frequency, percentage, chi square $(n=17)$ and significance for the statements about opportunities for ICT-integration

\begin{tabular}{|c|c|c|c|c|c|c|}
\hline S.No & "Statement & $\begin{array}{c}\text { Agreed } \\
\mathrm{f}(\%)\end{array}$ & $\begin{array}{l}\text { UND } \\
\mathrm{f}(\%)\end{array}$ & $\begin{array}{l}\text { Disagreed } \\
\mathrm{f}(\%)\end{array}$ & $\begin{array}{l}\text { Chi square } \\
\left(\chi^{2}\right)\end{array}$ & $\begin{array}{c}\text { Inference } \\
\chi_{0.05}^{2} \\
\text { at d.f }=1\end{array}$ \\
\hline 39 & $\begin{array}{l}\text { There are opportunities to link institutions with } \\
\text { the community in the form of telecenter. }\end{array}$ & $\begin{array}{c}10 \\
(58.82)\end{array}$ & $\begin{array}{c}1 \\
(5.88)\end{array}$ & $\begin{array}{c}5 \\
(29.41)\end{array}$ & 1.70 & $\begin{array}{c}\text { In significant } \\
\text { (Agreed) }\end{array}$ \\
\hline 40 & $\begin{array}{l}\text { There are opportunities to motivate in-service } \\
\text { teachers for learning skills to teach with the ICT. }\end{array}$ & $\begin{array}{c}15 \\
(88.23)\end{array}$ & $\begin{array}{c}0 \\
(0.0)\end{array}$ & $\begin{array}{c}2 \\
(11.76)\end{array}$ & 9.94 & $\begin{array}{l}\text { Significant } \\
\text { (Agreed) }\end{array}$ \\
\hline 41 & $\begin{array}{l}\text { There is opportunity to integrate ICT and } \\
\text { pedagogy in the contents of teacher training in } \\
\text { Pakistan. }\end{array}$ & $\begin{array}{c}12 \\
(70.6)\end{array}$ & $\begin{array}{c}2 \\
(11.76)\end{array}$ & $\begin{array}{c}3 \\
(17.64)\end{array}$ & 4.99 & $\begin{array}{l}\text { Significant } \\
\text { (Agreed) }\end{array}$ \\
\hline
\end{tabular}

Table 10 indicates that insignificant number of respondents agreed that there are opportunities to link institutions with the community in the form of telecenter while significant number of respondents agreed that there is opportunity to motivate in-service teachers and to integrate Information and Communication Technology in the contents of teacher training in Pakistan.

11. Present state of ICT-use for Teacher Training in Pakistan.

Table 11

Showing frequency, percentage, chi square $(n=17)$ and significance for the statements about present status of teacher training

\begin{tabular}{lcccccc}
\hline \hline S.No & Statement & Agreed & UND & Disagreed & Chi square & Inference \\
& & $\mathrm{f}(\%)$ & $\mathrm{f}(\%)$ & $\mathrm{f}(\%)$ & $\left(\chi^{2}\right)$ & $\begin{array}{c}\chi_{0.05}^{2} \\
\text { at d.f }=1\end{array}$ \\
& & & &
\end{tabular}




\begin{tabular}{|c|c|c|c|c|c|c|}
\hline 42 & $\begin{array}{l}\text { In Pakistan, the teacher training is provided by } \\
\text { face to face mode }\end{array}$ & $\begin{array}{c}7 \\
(41.17)\end{array}$ & $\begin{array}{c}1 \\
(5.88)\end{array}$ & $\begin{array}{c}9 \\
(52.94)\end{array}$ & 0.29 & $\begin{array}{l}\text { In significant } \\
\text { (Disagreed) }\end{array}$ \\
\hline 43 & $\begin{array}{l}\text { In Pakistan, the teacher training is provided in } \\
\text { online collaboration mode. }\end{array}$ & $\begin{array}{c}2 \\
(11.76)\end{array}$ & $\begin{array}{c}0 \\
(0.0)\end{array}$ & $\begin{array}{c}15 \\
(88.23)\end{array}$ & 9.94 & $\begin{array}{l}\text { Significant } \\
\text { (Disagreed) }\end{array}$ \\
\hline 44 & $\begin{array}{l}\text { In Pakistan, the teacher training is provided } \\
\text { offline/computer assisted mode. }\end{array}$ & $\begin{array}{c}3 \\
(17.64)\end{array}$ & $\begin{array}{c}3 \\
(17.64)\end{array}$ & $\begin{array}{c}11 \\
(64.70)\end{array}$ & 4.29 & $\begin{array}{l}\text { Significant } \\
\text { (Disagreed) }\end{array}$ \\
\hline
\end{tabular}

Table 11 indicates that insignificant number of respondents disagreed that teacher training is provided by face to face mode and significant number of respondents disagreed that teacher training is provided in online collaboration mode or offline/computer assisted mode.

\section{Possibilities of ICT-integration in Teacher Training of Pakistan.}

\section{Table 12}

Showing frequency, percentage, chi square $(n=17)$ and significance for the statements about possibilities of ICT-integration

\begin{tabular}{|c|c|c|c|c|c|c|}
\hline "S.No & 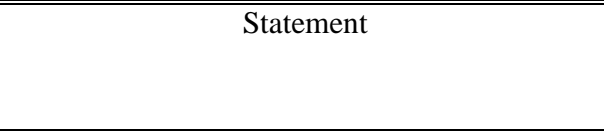 & $\begin{array}{c}\text { Agreed } \\
\mathrm{f}(\%)\end{array}$ & $\begin{array}{l}\text { UND } \\
f(\%)\end{array}$ & $\begin{array}{c}\text { Disagreed } \\
\mathrm{f}(\%)\end{array}$ & $\begin{array}{l}\text { Chi square } \\
\left(\chi^{2}\right)\end{array}$ & $\begin{array}{l}\text { Inference } \\
\chi_{0.05}^{2} \\
\text { at d.f }=1\end{array}$ \\
\hline 45 & $\begin{array}{l}\text { In Pakistan, there is possibility to provide teacher } \\
\text { training in online and collaboration mode. }\end{array}$ & $\begin{array}{c}13 \\
(76.47)\end{array}$ & $\begin{array}{c}2 \\
(11.76)\end{array}$ & $\begin{array}{c}2 \\
(11.76)\end{array}$ & 7.35 & $\begin{array}{l}\text { Significant } \\
\text { (Agreed) }\end{array}$ \\
\hline 46 & $\begin{array}{l}\text { In Pakistan, there are distance teacher training } \\
\text { program that utilize online and offline ICT } \\
\text { pedagogy for teacher professional development. }\end{array}$ & $\begin{array}{c}10 \\
(58.82)\end{array}$ & $\begin{array}{c}0 \\
(0.0)\end{array}$ & $\begin{array}{c}7 \\
(41.17)\end{array}$ & 0.52 & $\begin{array}{l}\text { In significant } \\
\text { (Agreed) }\end{array}$ \\
\hline 47 & $\begin{array}{l}\text { The infrastructure and facilities in teacher training } \\
\text { institute of Pakistan have the possibility to provide } \\
\text { ICT based integrated training program. }\end{array}$ & $\begin{array}{c}11 \\
(64.70)\end{array}$ & $\begin{array}{c}0 \\
(0.0)\end{array}$ & $\begin{array}{c}6 \\
(35.29(\end{array}$ & 1.46 & $\begin{array}{l}\text { In significant } \\
\text { (Agreed) }\end{array}$ \\
\hline 48 & $\begin{array}{l}\text { In Pakistan, the teacher training employ a } \\
\text { combination of teaching methodological i.e. } \\
\text { lectures/presentation, discussion etc. }\end{array}$ & $\begin{array}{c}13 \\
(76.47)\end{array}$ & $\begin{array}{c}0 \\
(0.0)\end{array}$ & $\begin{array}{c}4 \\
(23.5)\end{array}$ & 4.76 & $\begin{array}{l}\text { Significant } \\
\text { (Agreed) }\end{array}$ \\
\hline 49 & $\begin{array}{l}\text { In Pakistan, the teacher training employ project } \\
\text { based learning in which teacher work in teams. }\end{array}$ & $\begin{array}{c}5 \\
(29.41)\end{array}$ & $\begin{array}{c}4 \\
(23.5)\end{array}$ & $\begin{array}{c}8 \\
(47.05)\end{array}$ & 1.47 & $\begin{array}{l}\text { In significant } \\
\text { (Disagreed) }\end{array}$ \\
\hline 50 & $\begin{array}{l}\text { In Pakistan, the teacher training methods are based } \\
\text { on constructivist learning approaches where learners } \\
\text { are encouraged to participate in small group } \\
\text { discussion, peer projects, peer review activities in a } \\
\text { reflective learning experiences. }\end{array}$ & $\begin{array}{c}6 \\
(35.29)\end{array}$ & $\begin{array}{c}3 \\
(17.64)\end{array}$ & $\begin{array}{c}8 \\
(47.05)\end{array}$ & 0.76 & $\begin{array}{l}\text { In significant } \\
\text { (Disagreed) }\end{array}$ \\
\hline 51 & $\begin{array}{l}\text { In Pakistan, there is inquiry based critical thinking } \\
\text { and creativity based approaches employed in } \\
\text { training of teachers. }\end{array}$ & $\begin{array}{c}8 \\
(47.05)\end{array}$ & $\begin{array}{c}0 \\
(0.0)\end{array}$ & $\begin{array}{c}9 \\
(52.94)\end{array}$ & 0.06 & $\begin{array}{l}\text { In significant } \\
\text { (Disagreed) }\end{array}$ \\
\hline 52 & $\begin{array}{l}\text { In Pakistan, the teachers are trained to play the role } \\
\text { of facilitator and the students as self-disciplined, } \\
\text { self-regulated and using emotional intelligence and } \\
\text { self-motivation. }\end{array}$ & $\begin{array}{c}8 \\
(47.05)\end{array}$ & $\begin{array}{c}1 \\
(5.88)\end{array}$ & $\begin{array}{c}8 \\
(47.05)\end{array}$ & 0.06 & $\begin{array}{l}\text { In significant } \\
\text { (Disagreed) } \\
\text { and (Agreed) }\end{array}$ \\
\hline 53 & $\begin{array}{l}\text { In Pakistan, the method of training known as } \\
\text { cognitive apprenticeship is used in teacher training } \\
\text { programs. }\end{array}$ & $\begin{array}{c}12 \\
(70.6)\end{array}$ & $\begin{array}{c}1 \\
(5.88)\end{array}$ & $\begin{array}{c}4 \\
(23.5)\end{array}$ & 3.82 & $\begin{array}{l}\text { Significant } \\
\text { (Agreed) }\end{array}$ \\
\hline 54 & $\begin{array}{l}\text { In Pakistan, the teacher training program train } \\
\text { teachers to evaluate and assist students on the basis } \\
\text { of reflection and exploration. }\end{array}$ & $\begin{array}{c}9 \\
(52.94)\end{array}$ & $\begin{array}{c}1 \\
(5.88)\end{array}$ & $\begin{array}{c}7 \\
(41.17)\end{array}$ & 0.29 & $\begin{array}{c}\text { In significant } \\
\text { (Agreed) }\end{array}$ \\
\hline
\end{tabular}


Analysis of Teacher Education and Training Programs of Pakistan for ICT-Integration

55 In Pakistan, the teacher training program has three components: theory, practice and ICT (three dimensional approach).

$\begin{array}{ccccc}4 & 3 & 11 & 3.11 & \begin{array}{c}\text { Significant } \\ \text { (Disagreed) }\end{array} \\ (23.5) & (17.64) & (64.70) & & \end{array}$

Table12 indicates that significant number of respondents agreed that there is possibility to provide teacher training in online and collaboration mode and that the method of training known as cognitive apprenticeship is used in teacher training of Pakistan to facilitate it while insignificant number disagreed that the teacher training program at present has three components: theory, practice and Information and Communication Technology and there is inquiry based approaches employed in training of teachers in a constructivist environment.

13. Threats and challenges in ICT-integration in teacher training of Pakistan.

Table 13

Showing frequency, percentage, chi square $(n=17)$ and significance for the statements about threats and challenges

\begin{tabular}{|c|c|c|c|c|c|c|}
\hline S.No & Statement & $\begin{array}{c}\text { Agreed } \\
\text { f (\%) }\end{array}$ & $\begin{array}{l}\text { UND } \\
\mathrm{f}(\%)\end{array}$ & $\begin{array}{c}\text { Disagreed } \\
\text { f (\%) }\end{array}$ & $\begin{array}{c}\text { Chi square } \\
\left(\chi^{2}\right)\end{array}$ & $\begin{array}{c}\text { Inference } \\
\chi_{0.05}^{2} \\
\text { at d.f }=1\end{array}$ \\
\hline 56 & $\begin{array}{l}\text { In Pakistan, there are threats and challenges } \\
\text { such as religious groups, power crises, } \\
\text { connectivity and others to implement ICT } \\
\text { integrated teacher training strategies. }\end{array}$ & $\begin{array}{c}15 \\
(88.23)\end{array}$ & $\begin{array}{c}1 \\
(5.88)\end{array}$ & $\begin{array}{c}1 \\
(5.88)\end{array}$ & 11.58 & $\begin{array}{c}\text { Significant } \\
\text { (Agreed) }\end{array}$ \\
\hline
\end{tabular}

Table 13 indicates that significant number of respondents agreed that there are threats and challenges to implement ICT-integrated teacher training strategies such as: power crises, internet connectivity and accessibility etc.

\section{Attitude and perception of teacher towards ICT integration in Teacher Training of Pakistan.}

Table 14

Showing frequency, percentage, chi square $(n=17)$ and significance for the statements about attitude and perception

\begin{tabular}{|c|c|c|c|c|c|c|}
\hline S.No & Statement & $\begin{array}{l}\text { Agreed } \\
\text { f (\%) }\end{array}$ & $\begin{array}{l}\text { UND } \\
\mathrm{f}(\%)\end{array}$ & $\begin{array}{l}\text { Disagreed } \\
\mathrm{f}(\%)\end{array}$ & $\begin{array}{c}\text { Chi square } \\
\left(\chi^{2}\right)\end{array}$ & $\begin{array}{c}\text { Inference } \\
\chi^{2}{ }_{0.05} \\
\text { at d.f }=1\end{array}$ \\
\hline "57 & $\begin{array}{l}\text { In Pakistan, the teacher educators have positive } \\
\text { attitude towards using ICT in their personal life. }\end{array}$ & $\begin{array}{c}12 \\
(70.6)\end{array}$ & $\begin{array}{c}2 \\
(11.76)\end{array}$ & $\begin{array}{c}3 \\
(17.64)\end{array}$ & " 5.00 & $\begin{array}{l}\text { Significant } \\
\text { (Agreed) }\end{array}$ \\
\hline 58 & $\begin{array}{l}\text { In Pakistan, the perceptions of students teacher, } \\
\text { community and the government as well as } \\
\text { administration is positive towards integrating } \\
\text { ICT with curricula. }\end{array}$ & $\begin{array}{c}9 \\
(52.94)\end{array}$ & $\begin{array}{c}2 \\
(11.76)\end{array}$ & $\begin{array}{c}5 \\
(29.41)\end{array}$ & 1.47 & $\begin{array}{l}\text { In significant } \\
\text { (Agreed) }\end{array}$ \\
\hline
\end{tabular}

Table 14 indicates that significant number of respondents agreed that the attitude and perception of teacher educator, student teachers, government and administration in Pakistan is positive towards integration of Information and 


\section{Discussion}

Any program for education and training of teachers is implemented in a country on the basis of policy framework for that program, so without provision of policy guidelines for implementation of ICT-integration in teacher training of Pakistan, it will be impossible to provide other related facilities such as: curriculum, training modules, infrastructure, connectivity and trained staff etc.

The teacher education and training program is effective only when it is based on concrete objectives. So, there must be objectives in all aspects: cognitive (knowledge), affective (attitude and disposition) and psychomotor (skill and habit) for ICT-integration in teacher training and education. In Pakistan, the new trend is standard based teacher education and there is a professional standard that the teachers must have knowledge, skill and disposition in Information and Communication Technology.

For ICT integration in teacher education and training not only the teachers but other staff such as Headmasters, Principals and other non-teaching staff are also required to make its useful, more effective.

For integration of Information and Communication Technology in teacher training as a media, it is necessary need to include all levels from elementary and secondary to collegiate and university levels while presently in Pakistan, there is no provision to have training teachers with Information and Communication Technology even for short duration.

ICT-integrated teacher training requires the teacher educator having experience of the effective use of Information and Communication Technology. When the instructors or trainers are lacking the knowledge and skills and disposition to use Information and Communication Technology, how they can develop ICT trained students and the teacher, so training will be ineffective.

The ICT-integrated teacher training also require curriculum and training modules to be developed according to the national, international and local needs of the country or state and in Pakistan, presently there is no step taken in this direction. It also requires pilot testing before its initiation.

Every curriculum and training module consists of contents and activities to be presented to the student teachers and their performance is evaluated in it. But, in Pakistan there are issues such as access to internet, energy crises, infrastructure inadequacy, religious conflict etc. that provide hindrances for the e-content presentation by the educators.

For ICT-integration in teacher training of Pakistan, there is the issue of econtent production and development for training modules because there is lake of expertise in the field of software application and programming and there is only pedagogy based Information and Communication Technology which is not integrated.

ICT-integrated teacher training in Pakistan requires that the teachers and students should have knowledge and skills to use Information and Communication 
Technology for online collaboration and video conferencing to meet the global requirements/standards of knowledge.

The ICT-integrated teacher training program of Pakistan has the opportunity to initiate it through in-service teacher training programs, because the present lot of teachers is unaware off this technology which hinders and discourages the new comers trained in pre-service and initial teacher training institutions with Information and Communication Technology competences.

Teacher training in Pakistan is imparted through both modes; face to face and open and distance learning. The most important mode is now open and distance learning because the geographic conditions of Pakistan and religious/cultural restrictions of girls to have higher education outside the home points to the new trend of Information and Communication Technology to resolve the issue and solve the problem of accessibility and gender parity.

The teacher training should be made three dimensional and there is possibility in Pakistan because it requires the inclusion of Information and Communication Technology only; while the existing program is already based on cognitive apprenticeship and on constructivist approaches as well are used in teaching.

The ICT-integrated teacher training program in Pakistan will face the threatsof internet connectivity, energy crises and other issues and problems but these should be faced with challenges and determination to resolve and solve.

The most important hindrance is the perception and attitude of teachers, administration, community and government but, here the perception and attitude is positive towards integration of Information and Communication Technology in teacher training program of Pakistan.

\section{Conclusions}

On the basis of findings and discussion the following conclusion are drawn:

1. For ICT-integration in teacher training a policy framework is required to be developed in Pakistan.

2. In Pakistan, the objectives of teacher training must include Information and Communication Technology related knowledge, skill and attitude.

3. The whole school Information and Communication Technology literacy campaign will be needed to broaden its scope to the community.

4. ICT-integration in teacher training requires its introduction as a media of instruction at all levels: school, college and university to make it need base integrated in teacher training.

5. Information and Communication Technology integrated teacher training will be initiated from the educators or trainers so that they must be trained first for the purpose to become effective and efficient educators.

6. Before, initiating ICT-integrated teacher training programs the issue of curriculum and modules development needs to be resolved first.

7. The issue of access to internet, energy crises, development of infrastructure etc. needs to be resolved for ICT-integration in teacher training of Pakistan.

8. The issue of e-content production and development need to be resolved by linking teacher training to the professionals in the fields of computer science and 
software engineering to produce and develop ICT-integrated softwares and programs for e-contents production and development in training modules.

9. The school curriculum also needs to be revised and reviewed to have integrated ICT for developing the skill of teachers and students to use online tools for communication, collaboration and community networking.

10. Most of the teachers are trained in Pakistan but they need the new knowledge and skill in Information and Communication Technology to be developed through inservice teacher training crash programs in the form of cascade training and peer reviewing.

11. The present infrastructure can be used for ICT-integrated teacher training programed to have more access and effectiveness especially for girls and remote areas students.

12. There is the possibility to integrate ICT in teacher training of Pakistan because the program has rich infrastructure and supportive constructivist environment.

13. A resolve and commitment is required to face the threats and challenges for ICTintegration in teacher training program of Pakistan.

14. The positive attitude of teachers should be utilized for introducing ICT-integrated curricula in all types and levels of teacher training program and to provide the facilities needed for its initiation and implementation.

\section{Recommendations}

To integrate Information and Communication Technology in teacher training program of Pakistan, study recommends its conclusions to be used as a vision and for strategic planning in future; to keep pace with the new trends and developments in teacher training and higher education in the world and to face the challenges in the field of education and in Open and Distance Learning.

There is possibility to integrate ICT in teacher training of Pakistan but that requires political will and strong commitment to face the threats and convert them into opportunities and challenges to keep pace with the globalization and its emerging needs, trends and issues in teacher education through Open and Distance Learning.

The study suggests further research to explore how to integrate ICT in pedagogy, e-content design and delivery in teacher education programs of Pakistan.

\section{REFERENCES}

Afzal, T,M (2009); impact of using Mathematics software on students' learning achievement at elementary level. Ph.D thesis. University of Education Lahore.

Agherdien. N (2007); Ph.D thesis. Johannes Berg University. South Africa.

Agastinho, S.et al (2002). A tool to evaluate the potential for an ICT-based learning design to foster "high-quality learning". University of Wollongong, Research online

Brooks, J.G and Brooks, M.G (1999); In search of understanding: The case for Constructivist classrooms. Alexandria, Association for Supervision and Curriculum Development.

D'Silva, A.et al (nd). Information and Communication Technology (ICT) in Teacher Education: Effective sets of tools for learning. Notre Dame Institute of Education Pakistan.

Government of Pakistan (2004). Teacher Education in Pakistan: A position paper. 
Ministry of Education, Pakistan

Government of Pakistan (2009). National Professional Standard for Teacher in

Pakistan. Policy and planning wing, Ministry of Education, Pakistan

Joyce, B. and Weil. M (1996); Models of Teaching. Boston, Allyn and Bacon.

Lim,P.C (2002); A theoretical frame work for the study of ICT in school; proposal.

British Journal of Educational Technology Vol 33 No.4 Pp. 411-421.

Mishra, P. and J. Keohler, M(2006); Technological pedagogical context knowledge:

A frame work for teacher knowledge. Michigan State University.

Otieno, J.O (2008); A framework for evaluating ICT use in teacher education. Strathmore University.

Sulcic, V. and Sulcic, J (2007): Can online tutor improve the quality of e-learning. UP faculty of Management, Koper, Slovenia.

Tondeur, J.et al (2007). Curricula and the use of ICT in Education: Two worlds apart? British Journal of Educational Technology Vol 38 No.6 Pp. 962-976.

UNESCO (2007). Situation Analysis of Teacher Education: Towards a strategic Framework for Teacher Education and Professional Development: USAID, Pakistan. Unesco.org.pk 